\title{
Kinetic Studies on Alcoholic Fermentation Under Substrate Inhibition Conditions Using a Bioreactor with Stirred Bed of Immobilized Yeast Cells
}

\author{
Anca-Irina Galaction ${ }^{1}$, Anca-Marcela Lupăşteanu ${ }^{2}$ and Dan Caşcaval ${ }^{*}, 2$ \\ ${ }^{I}$ University of Medicine and Pharmacy "Gr.T. Popa" of Iasi, Faculty of Medical Bioengineering, Dept. of Medical \\ Biotechnologies, M. Kogalniceanu 9-13, 700454, Iasi, Romania \\ ${ }^{2}$ Technical University "Gheorghe Asachi” of Iasi, Faculty of Chemical and Environmental Engineering, Dept. of \\ Biochemical Engineering, D. Mangeron 71, 700050, Romania
}

\begin{abstract}
The studies on the alcoholic fermentation with immobilized $S$. cerevisiae cells on alginate using a bioreactor with stirred beds of biocatalysts indicated that the diffusion inside the biocatalyst particles attenuates or avoids the inhibitory effects, preserving the microbial activity. Using a mathematical model adequate for ethanol formation in heterogeneous systems the kinetic parameters $\mathrm{V}, \mathrm{K}_{\mathrm{I}}$ and $\mathrm{K}_{\mathrm{M}}{ }_{\mathrm{M}}$ have been estimated. Therefore, the obtained values of $\mathrm{V}$ and $\mathrm{K}_{\mathrm{M}}$ were found to be higher than those corresponding to the homogeneous media under ethanol inhibition, but lower than those for homogeneous media without inhibitory fenomena.
\end{abstract}

Keywords: Stirred bed, immobilized cells, yeasts, alcoholic fermentation, kinetic.

\section{INTRODUCTION}

The "white biotechnology", the new concept promoted at the International Conference "European Bioperspectives - En Route to a Knowledge-Based Bio-Economy" (Cologne, Germany, May 31 - June 1 2007), proclaims that the use of renewable raw materials for biofuels production by lowexpensive and ecofriendly biotechnologies constitutes one of the priority of industrial activities [1].

Among the tested and currently used biofuels, the bioethanol represents an attractive alternative to the conventional fossil fuels, its production by converting various substrates by free or immobilized cells of bacteria (Clostridium sp.) or yeasts (Saccharomyces sp., Zymomonas $s p$.) being intensively studied in the last two decades [2-5].

The fermentation with immobilized cells avoids the substrate inhibition, in these systems the use of higher concentration of carbohydrates becoming poosible, allows the easier recovery of biocatalysts and attenuates the reduction of the microbial activity. Therefore, the biocatalysts can be reused for many fermentation cycles $[1,3,5]$.

Among the bioreactors with immobilized biocatalysts, those with stirred/mobile beds are the most attractive ones, owing to their constructive and operational similitude to the well-known stirred bioreactors. But, as it can be observed from literature, most of the experiments on alcoholic fermentation with immobilized cells have been carried out in fixed bed bioreactors in continuous, semicontinuous or fedbatch systems [2-13]. The fixed beds of immobilized cells have been preferred due to the higher sensitivity of the

\footnotetext{
*Address correspondence to this author at the Technical University "Gheorghe Asachi" of Iasi D. Mangeron 71, 700050 Iasi, Romania; Fax: 0040232271311; E-mail: dancasca@ch.tuiasi.ro, dancasca@from.ro
}

immobilized cells or enzymes to the forces generated by the impellers.

Our previous studies on alcoholic fermentation performed in a bioreactor with stirred beds of immobilized $S$. cerevisiae cells in alginate indicated that it is possible to reach very efficient mixing without or with minimum loss of biocatalyst physical integrity by selecting the optimum impellers combination [14-16]. These studies have been dedicated to the analysis of the medium circulation for different biocatalysts particles sizes and volumetric fractions using seven types of radial impellers. The results have been directly correlated with the shear effects on the immobilized cells particles [17].

The previous experiments are continued by investigating the kinetics of alcoholic fermentation of glucose under substrate inhibition limitation and by developing a mathematical model describing the internal diffusion of the substrate and, implicitly, the distribution of substrate concentration inside the biocatalysts particle. In this paper, the kinetic study of glucose conversion into ethanol is presented.

\section{MATERIALS AND METHODOLOGY}

The experiments have been carried out in 51 (4 1 working volume) laboratory bioreactor (Biostat A, B. Braun Biotech International), with computer-controlled and recorded parameters [18].

The mixing equipment consists of two pitched bladed turbines of $64 \mathrm{~mm}$ diameter and three baffles. The inferior impeller has been placed at $64 \mathrm{~mm}$ from the bioreactor bottom. The superior impeller was placed on the same shaft at a distance of $32 \mathrm{~mm}$ from the inferior one. The rotation speed was maintained at $250 \mathrm{rpm}$, thus value avoiding the "cave" formation at the broths surface, solid phase deposition at the bioreactor bottom and mechanical 
disruption of the biocatalysts particles. According to the previous results, these impellers combination and rotation speeds were found to be the optimum ones for the investigated fermentation system [14-17]. Any mechanical damage of the biocatalyst due to the shear forces was recorded during the experiments.

In the experiments, immobilized $S$. cerevisiae cells in alginate have been used. The immobilization has been carried out by cells inclusion into the alginate matrix, respecting the method given in literature [8]. The following diameters of the biocatalyst spherical particles have been obtained: 4, 4.6 and $5.2 \mathrm{~mm}$. The volumetric fraction of the immobilized cells into the medium was varied between 0.07 and 0.40

The composition of the medium was: glucose 50,100 or $150 \mathrm{~g} / \mathrm{l}, \mathrm{KH}_{2} \mathrm{PO}_{4} 5 \mathrm{~g} / \mathrm{l},\left(\mathrm{NH}_{4}\right)_{2} \mathrm{SO}_{4} 2 \mathrm{~g} / 1, \mathrm{MgSO}_{4} 0.2 \mathrm{~g} / \mathrm{l}$, yeast extract $2 \mathrm{~g} / \mathrm{l}$, tap water to the prescribed volume [19]. The fermentations have been carried out until the entire amount of glucose was consumed, at $28^{\circ} \mathrm{C}$.

The process evolution has been analyzed by means of the variation of glucose and ethanol concentrations during the fermentation. The concentrations of the two compounds have been measured by high performance liquid chromatography technique (HPLC) with a Phenomenex Rezex ROA column (7.8 $\mathrm{mm}$ diameter, $300 \mathrm{~mm}$ length), provided with the refractive index detector RID-10A. The mobile phase was a solution of $5 \times 10^{-3} \mathrm{~N}$ sulfuric acid with a flow rate of 0.6 $\mathrm{ml} / \mathrm{min}$. The analysis temperature was of $65^{\circ} \mathrm{C}$.

\section{RESULTS AND DISCUSSION}

\section{Glucose Consumption}

The bacteria or yeasts posses the ability to converse glucose under anaerobic conditions by Embden-MereyhofParnas metabolic pathway, the main final products being the ethanol and carbon dioxide [20,21]. The efficiency of ethanol production by yeasts can be affected by glucose or ethanol concentration, due to the specific phenomenon of substrate or product inhibition. In these circumstances, the viability of $S$. cerevisiae population, the substrate consumption and ethanol biosynthesis rates are directly controlled by the cultivation conditions. An interesting result has been obtained by Nagodawithana and Steinkraus, the authors concluding that the addition of ethanol in a culture of $S$. cerevisiae induces less toxic effect than that generated by ethanol biosynthesized during the fermentation, the cells death occurring with lower rate in the former case [22]. This result could be explained by the presence of other metabolic products beside ethanol, these secondary products contributing to the amplification of the inhibitory phenomenon.

The experimental studies presented in this paper have been carried out at various glucose concentrations into the medium, some of them higher than the level generating the substrate inhibition for the fermentation systems with free yeast cells. Because the previous studies indicated that the optimum biocatalyst diameter from the viewpoint of mixing efficiency and particle mechanical lysis is that of $4.6 \mathrm{~mm}$, the results will be analyzed in relation with this size of particle.
The initial analysis of the results plotted in Figs. (1-3) suggests that the immobilized yeast cells can be used for several fermentation cycles, the magnitude of the modification of biocatalyst activity being correlated with the particles characteristics and substrate initial concentration.

For biocatalyst particles with $4.6 \mathrm{~mm}$ diameter and lower volumetric fraction $(\phi=0.07)$, at an initial glucose concentration of $50 \mathrm{~g} / \mathrm{l}$, the duration of the first fermentation is of $26 \mathrm{~h}$ (necessary for the total consumption of glucose) (Fig. 1). Any important modification of the yeast activity has been observed during the first four fermentation cycles, but the glucose consumption rate decreases and, implicitly, the process duration increases significantly from the fermentation $\mathrm{V}$ to IX. Therefore, the duration of fermentation IX becomes of $50 \mathrm{~h}$, but other few fermentation cycle could be performed until reaching $72 \mathrm{~h}$ (this duration is required for the primary, main and complementary alcoholic fermentation with free $S$. cerevisiae cells).

The increase of the initial glucose concentration to 100 $\mathrm{g} / \mathrm{l}$ does not change the shape of the plotted variations, but it extends the time interval needed for reaching the total consumption of substrate. According to Fig. (1), the fermentation duration increases from $38 \mathrm{~h}$, cycle I, to $70 \mathrm{~h}$, cycle VII. Moreover, only the first two fermentation cycles occurred similarly, the variations of glucose concentration becoming differentiated after the second cycle.

The utilization of $150 \mathrm{~g} / \mathrm{l}$ glucose, level that corresponds to the appearance of the evident substrate inhibition, does not inhibit the activity of the immobilized yeast cells (Fig. 1). Furthermore, the amounts of converted substrate for a certain time interval are rather equal, indifferent of its concentration in medium. This result suggests that the substrate inhibition is avoided by cells immobilization, owing to the internal diffusion of the substrate inside the biocatalyst particles which reduces the inner glucose concentration bellow that inducing the inhibition.

Starting from an initial substrate concentration of $150 \mathrm{~g} / \mathrm{l}$, the fermentation duration is significantly increased (from 100 to $160 \mathrm{~h}$ from fermentation I to $\mathrm{V}$ ), simultaneously with the amplification of the differences between the glucose consumption rates from one fermentation cycle to another.

The above conclusions are valid also for higher biocatalyst particles concentration in bioreactor, but the duration of the fermentation is considerably reduced. Thus, from Fig. (1) it can be seen that for $\phi=0.40,50 \mathrm{~g} / 1$ glucose is entirely consumed in $20 \mathrm{~h}, 100 \mathrm{~g} / 1$ glucose in $26 \mathrm{~h}, 150 \mathrm{~g} / 1$ glucose in $62 \mathrm{~h}$, respectively. Moreover, indifferent of the initial substrate concentration, nine fermentation cycles are possible before reaching the overall process duration corresponding to the fermentation with free $S$. cerevisiae cells, the recorded variations of glucose concentration being closer.

Although for biocatalyst particles with diameters of 4 and $5.2 \mathrm{~mm}$ the shape of the curves describing the variation of glucose concentration during the fermentation and the conclusions drawn from their analysis are rather similar to those above discussed, different glucose consumption rates can be observed in function of biocatalyst particles 


$$
\phi=0.07
$$

$\mathrm{C}_{\mathrm{S}}=50 \mathrm{~g} / 1$

$\phi=0.40$
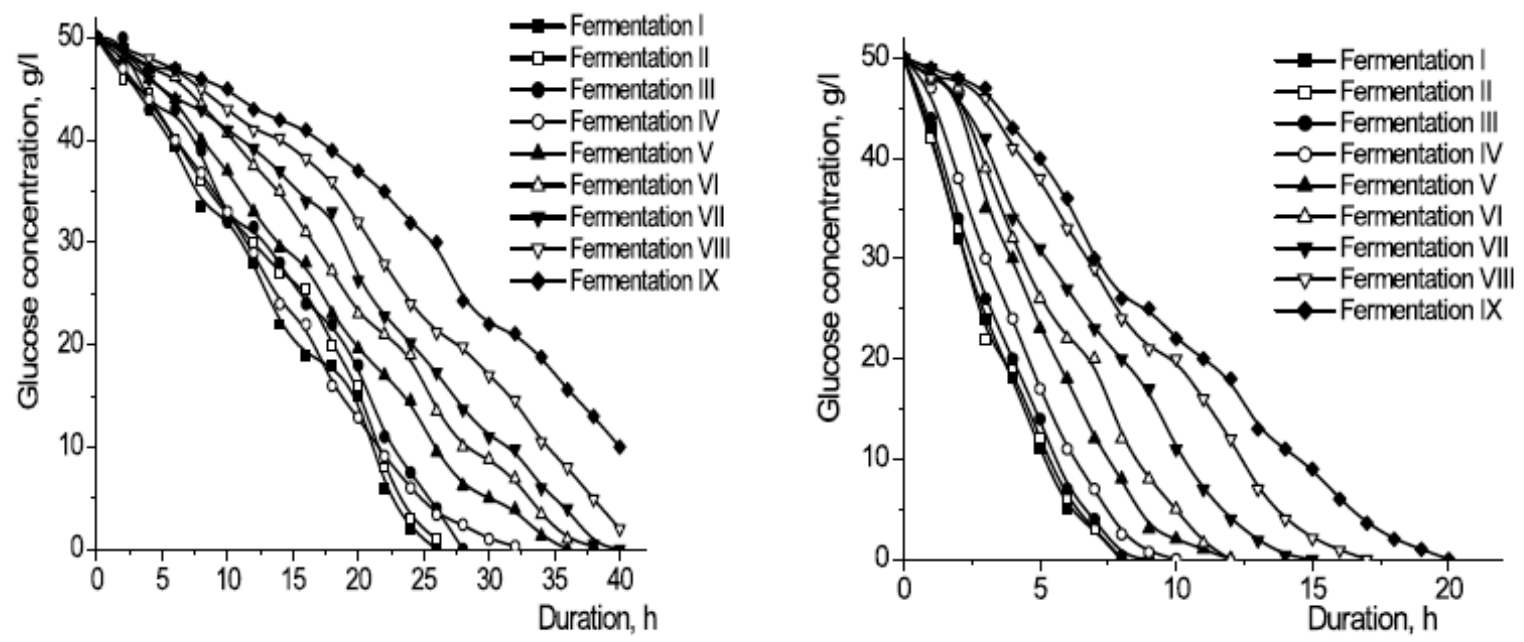

$$
\phi=0.07
$$

$\mathrm{C}_{\mathrm{S}}=100 \mathrm{~g} / 1$

$\phi=0.40$
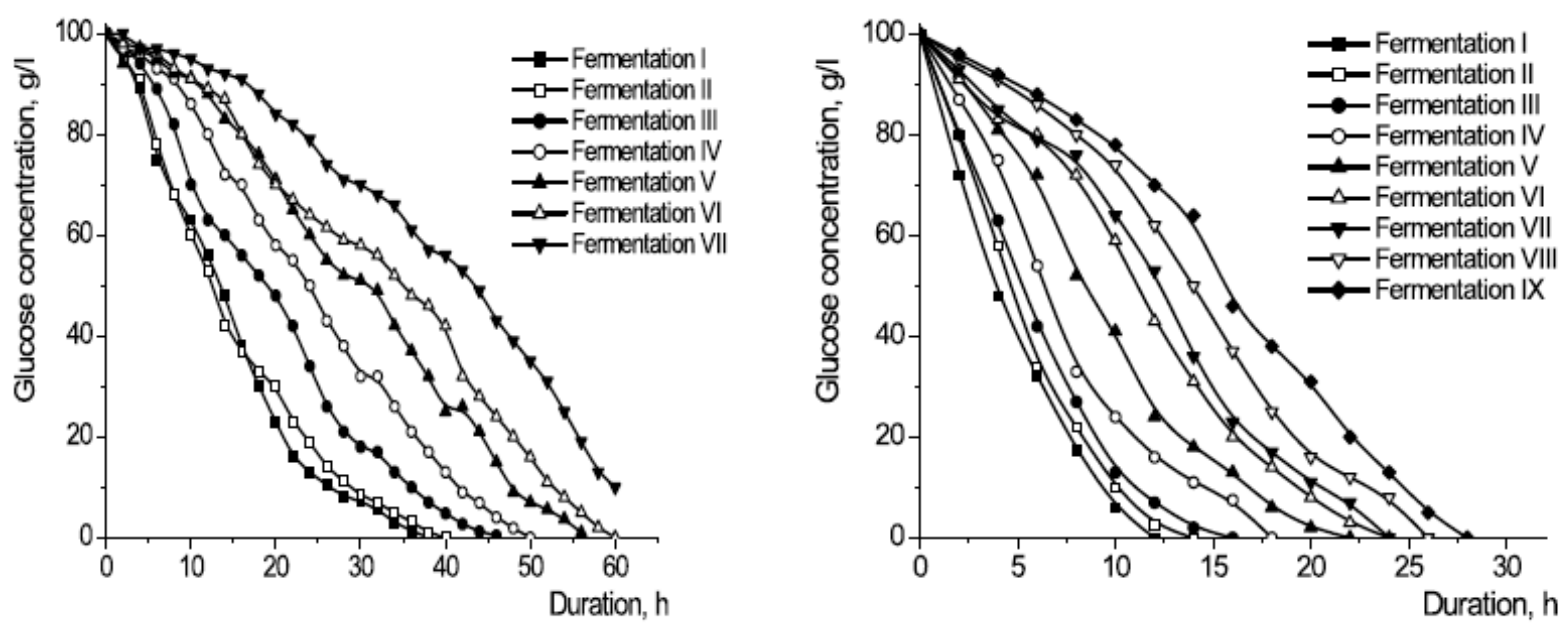

$$
\phi=0.07
$$

$$
\mathrm{C}_{\mathrm{S}}=150 \mathrm{~g} / 1
$$

$\phi=0.40$
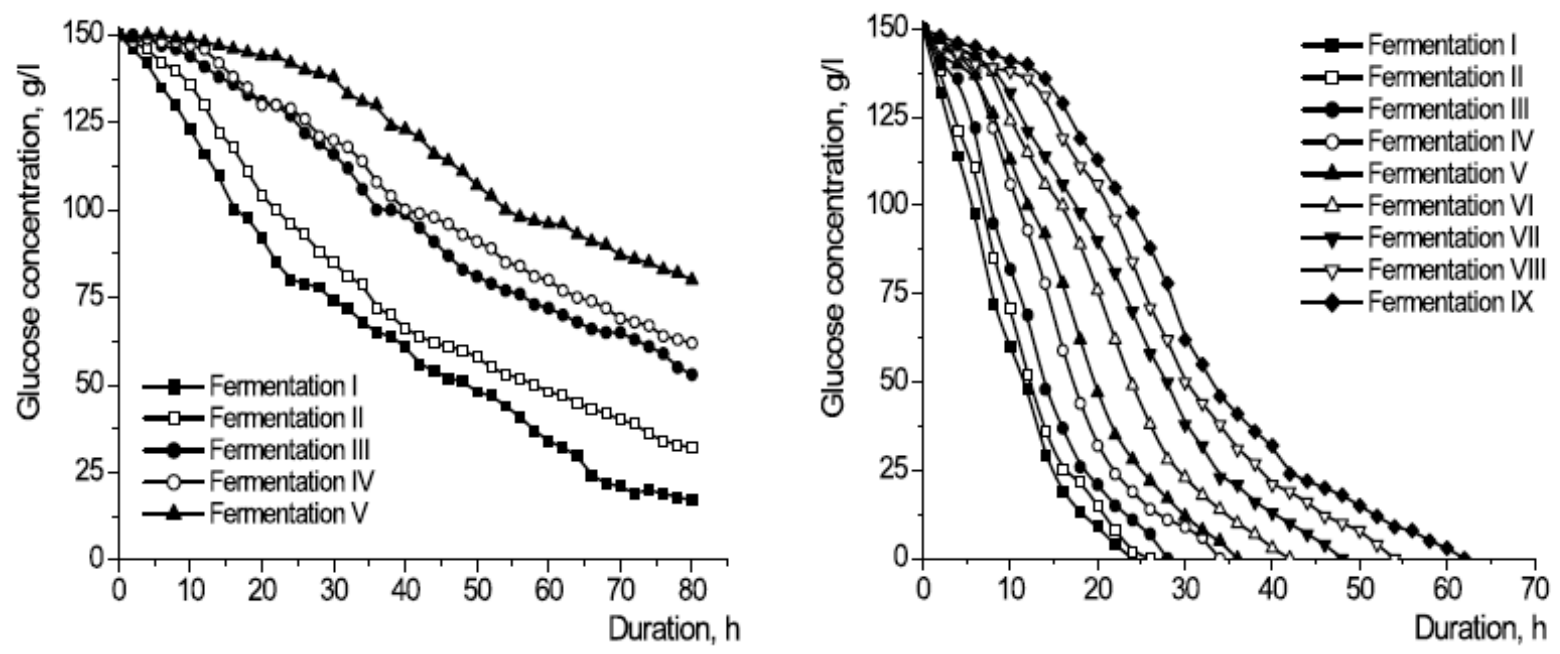

Fig. (1). Variation of glucose concentration for biocatalyst particles diameter of $4.6 \mathrm{~mm}$. 


$$
\mathrm{C}_{\mathrm{S}}=50 \mathrm{~g} / 1
$$

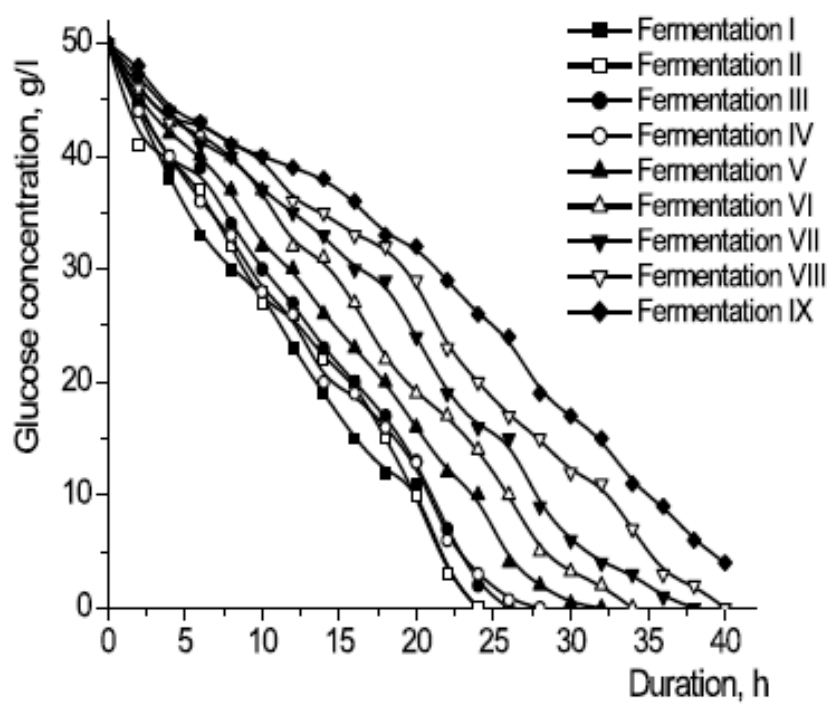

$$
\mathrm{C}_{\mathrm{S}}=150 \mathrm{~g} / 1
$$

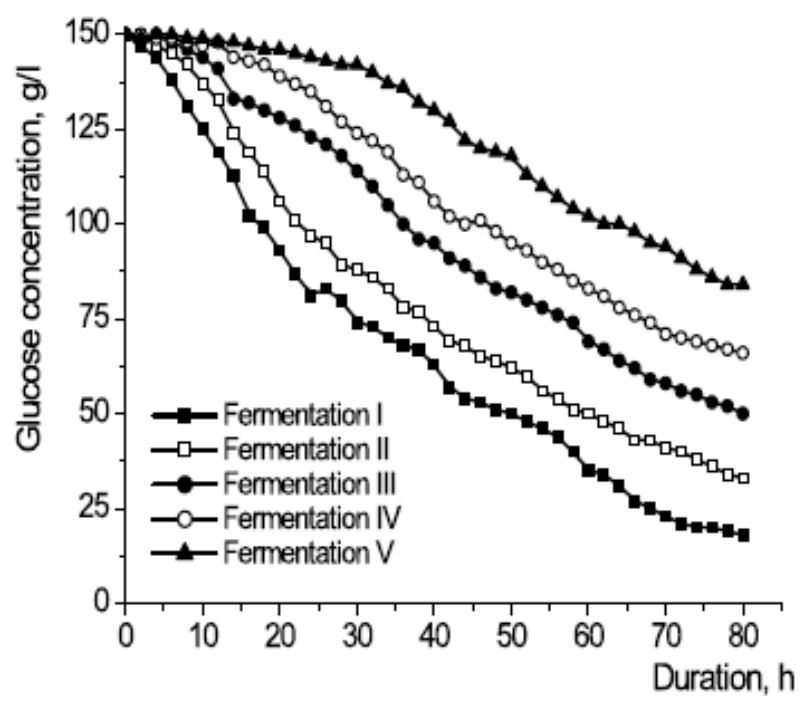

$$
\mathrm{C}_{\mathrm{S}}=100 \mathrm{~g} / 1
$$

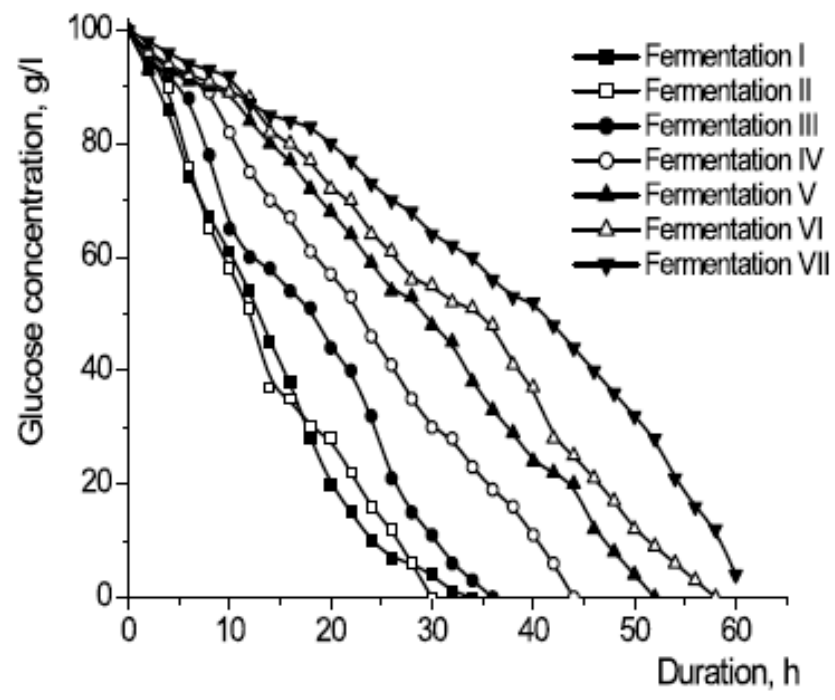

Fig. (2). Variation of glucose concentration for biocatalyst particles diameter of $4 \mathrm{~mm}$ and $\phi=0.07$.

characteristics. Therefore, for the smallest particles and volumetric fraction of 0.07 , at glucose initial concentration of $50 \mathrm{~g} / \mathrm{l}$ the fermentation duration is inferior to that reached for particles with $4.6 \mathrm{~mm}$ diameter, the time needed for total consumption of the substrate varying between $24 \mathrm{~h}$, for fermentation I, and $45 \mathrm{~h}$, for fermentation IX (Fig. 2). The acceleration of the process rate is maintained also for glucose concentration of $100 \mathrm{~g} / \mathrm{l}$, the maximum fermentation duration being of $62 \mathrm{~h}$ for the seventh cycle.

The ratio between the substrate consumption rates recorded for the biocatalyst particles diameters of 4 and 4.6 $\mathrm{mm}$ is changed for a medium initially containing $150 \mathrm{~g} / \mathrm{l}$ glucose (Fig. 2). In this case, the utilization of the smallest particles increases the time required for the entire glucose consumption. This inversion is the consequence of the more important resistance to the diffusion of glucose inside the biocatalyst for the particles with $4.6 \mathrm{~mm}$ diameter. The magnitude of resistance to the internal diffusion is directly related to the particle size and controls the glucose concentration gradient between the inner and outer regions of the particle. Thus, this gradient is increased by reducing the internal diffusion velocity, and, consequently, the internal concentration of substrate could be lower than that inducing the inhibition phenomenon for the biocatalyst particles with diameter of $4.6 \mathrm{~mm}$.

If the biocatalyst particles with $5.2 \mathrm{~mm}$ diameter are used, the time needed for total glucose consumption is increased to $78 \mathrm{~h}$, for fermentation IX at initial substrate 


$$
\mathrm{C}_{\mathrm{S}}=50 \mathrm{~g} / 1
$$

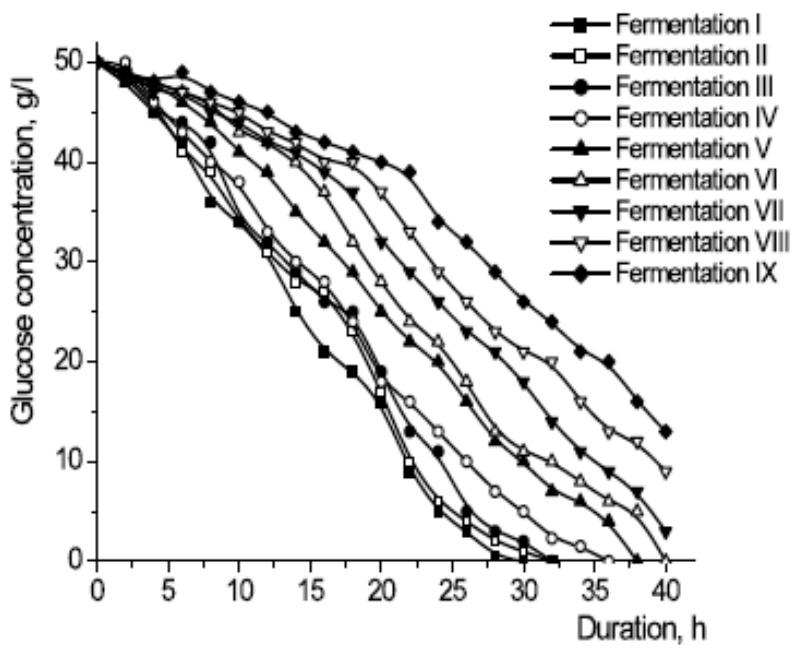

$$
\mathrm{C}_{\mathrm{S}}=150 \mathrm{~g} / 1
$$

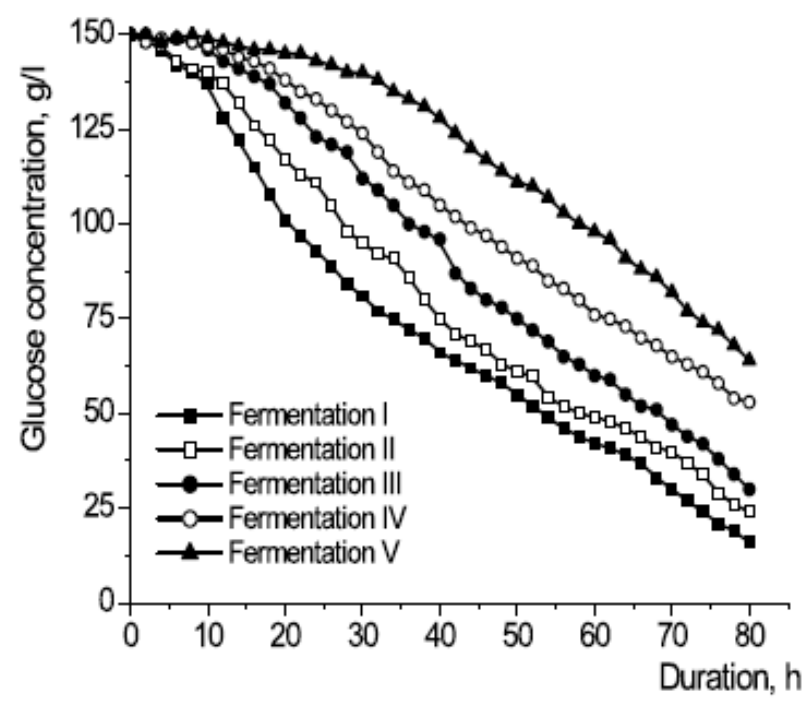

$$
\mathrm{C}_{\mathrm{S}}=100 \mathrm{~g} / 1
$$

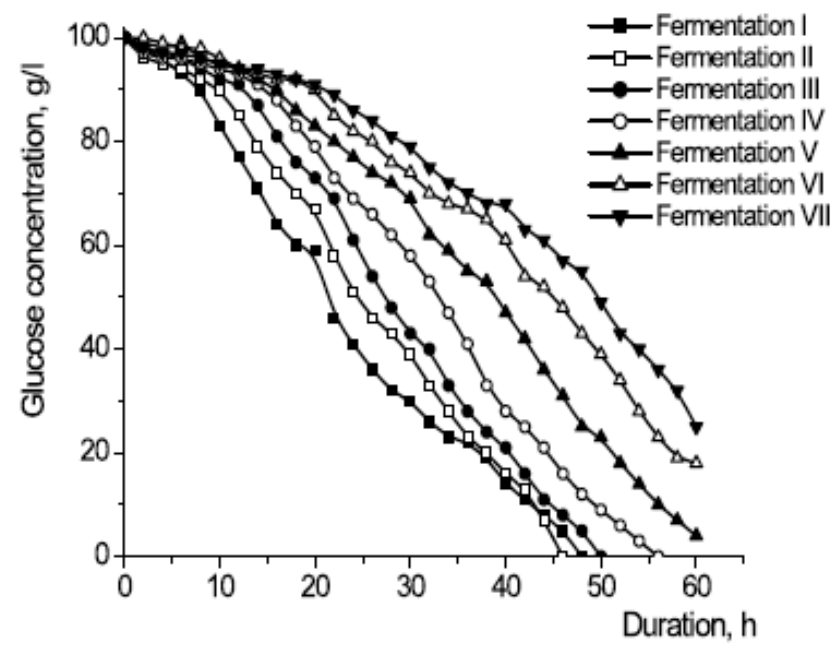

Fig. (3). Variation of glucose concentration for biocatalyst particles diameter of $5.2 \mathrm{~mm}$ and $\phi=0.07$.

concentration of $50 \mathrm{~g} / \mathrm{l}$, and over $80 \mathrm{~h}$, for fermentation VII at initial substrate concentration of $100 \mathrm{~g} / \mathrm{l}$, respectively (Fig. 3). Compared to the previous biocatalyst particles sizes, the glucose consumption from 150 to $0 \mathrm{~g} / 1$ is accelerated in the case of the biggest particles. After $80 \mathrm{~h}$ from the fermentation start, the glucose concentration reached the values of $16 \mathrm{~g} / 1$ for cycle I, respectively $64 \mathrm{~g} / 1$ for cycle $\mathrm{V}$, values that are significant lower that those recorded for the other two sizes of biocatalyst particles (Fig. 3). This result confirms that the internal diffusion contributes decisively to the diminution of the inhibitory effect of glucose. But, in this case, the product inhibition could become important, due to the low diffusion rate of ethanol towards the outer medium and to its accumulation inside the particle. However, the experiments indicated that the substrate inhibition represents the main phenomenon affecting the fermentation performance compared to the product inhibition.
These experiments have been carried out also at rotation speeds of 150,200 and $300 \mathrm{rpm}$, but any important modification of the above variations have been observed. Therefore, it can be concluded that the diffusion of glucose through the boundary layer at the biocatalyst particles surface does not represent the limitative step of the substrate consumption process.

\section{Ethanol Production}

Evidently, the variation of ethanol concentration during the fermentation is directly correlated with that of glucose concentration (Figs. 4-6). Furthermore, for a certain initial concentration of glucose, the values of ethanol concentration and fermentation duration are controlled by the size and concentration of biocatalyst particles.

As it was above discussed, the biocatalyst particles characteristics influence the glucose internal diffusion 
$\phi=0.07$

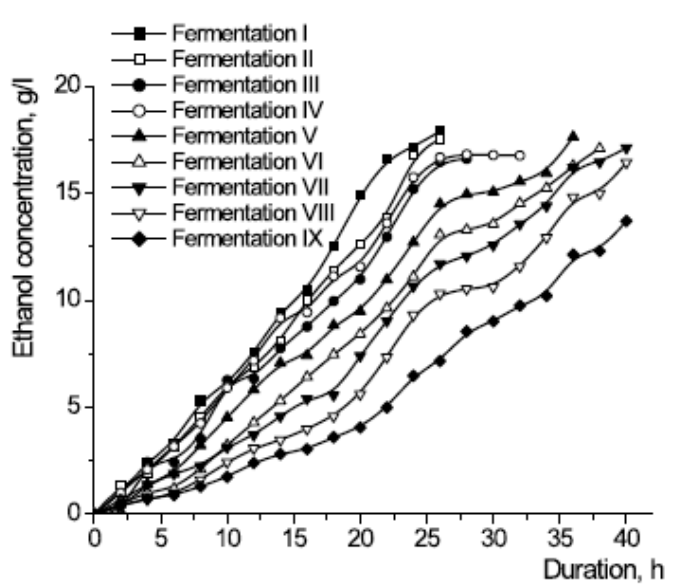

$\mathrm{C}_{\mathrm{S}}=50 \mathrm{~g} / 1$

$\phi=0.40$ $\phi=0.07$

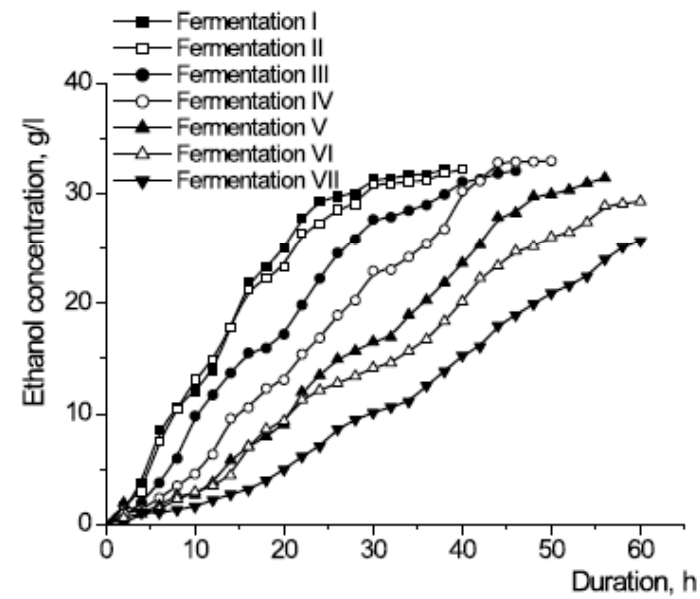

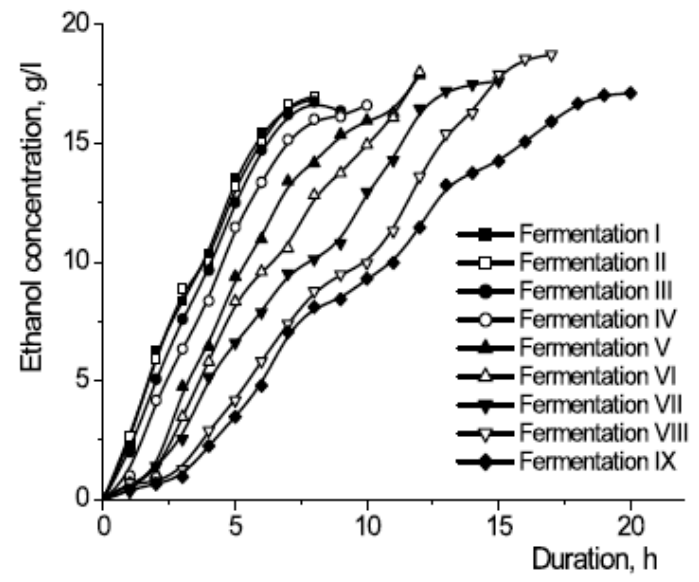

$\mathrm{C}_{\mathrm{S}}=100 \mathrm{~g} / 1$

$\phi=0.40$

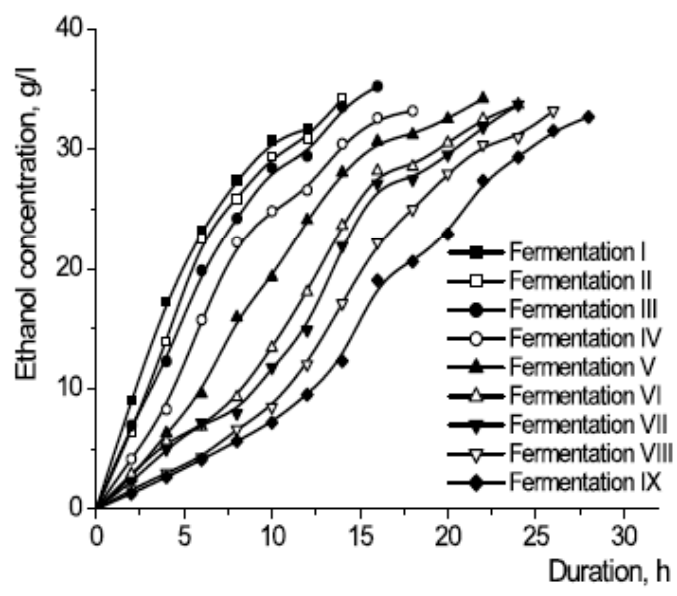

$\phi=0.07$

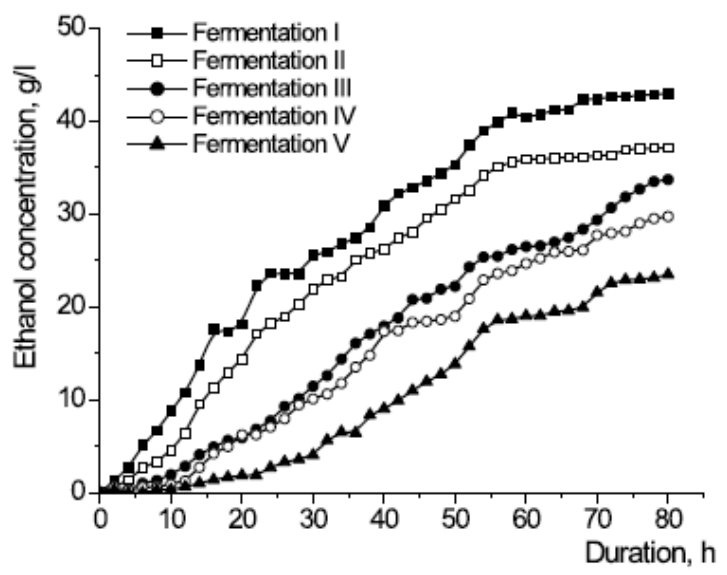

$\mathrm{C}_{\mathrm{S}}=150 \mathrm{~g} / 1$

$\phi=0.40$

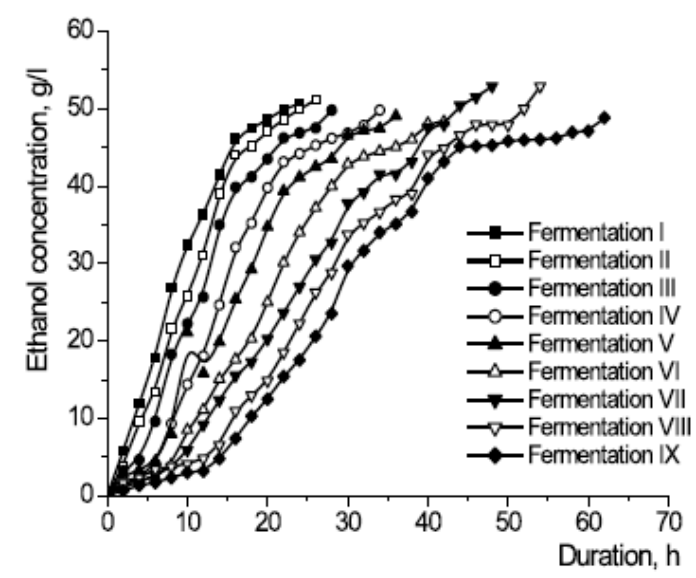

Fig. (4). Variation of ethanol concentration for biocatalyst particles diameter of $4.6 \mathrm{~mm}$.

velocity and consumption rate. Theoretically, from $180 \mathrm{~g}$ glucose is produced $92 \mathrm{~g}$ ethanol, the theoretical yield of substrate conversion being:

$$
Y_{P / S}=\frac{C_{P}}{C_{S c}}=0.51
$$




$$
\mathrm{C}_{\mathrm{S}}=50 \mathrm{~g} / 1
$$

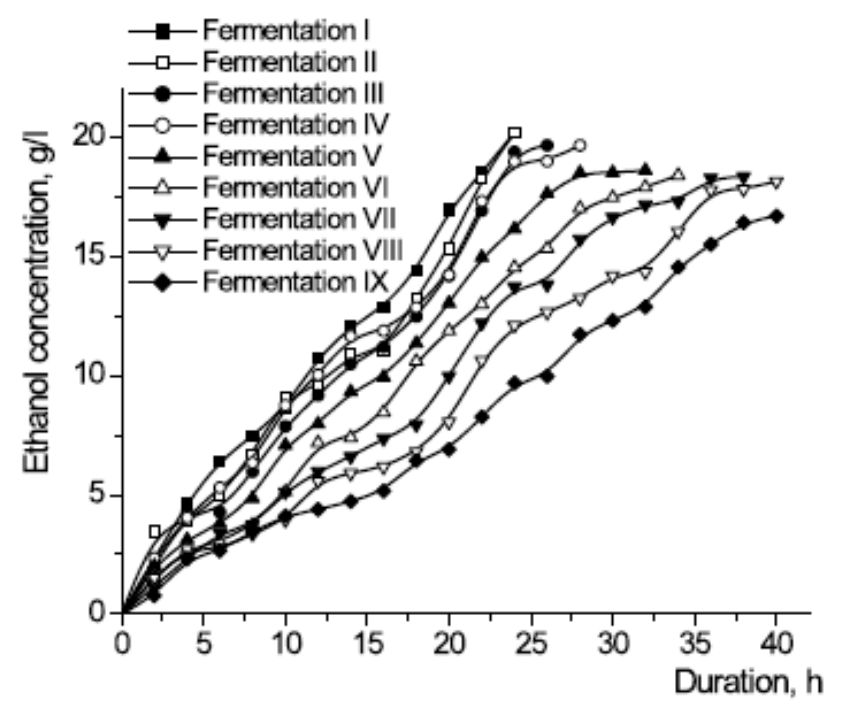

$$
\mathrm{C}_{\mathrm{S}}=100 \mathrm{~g} / 1
$$

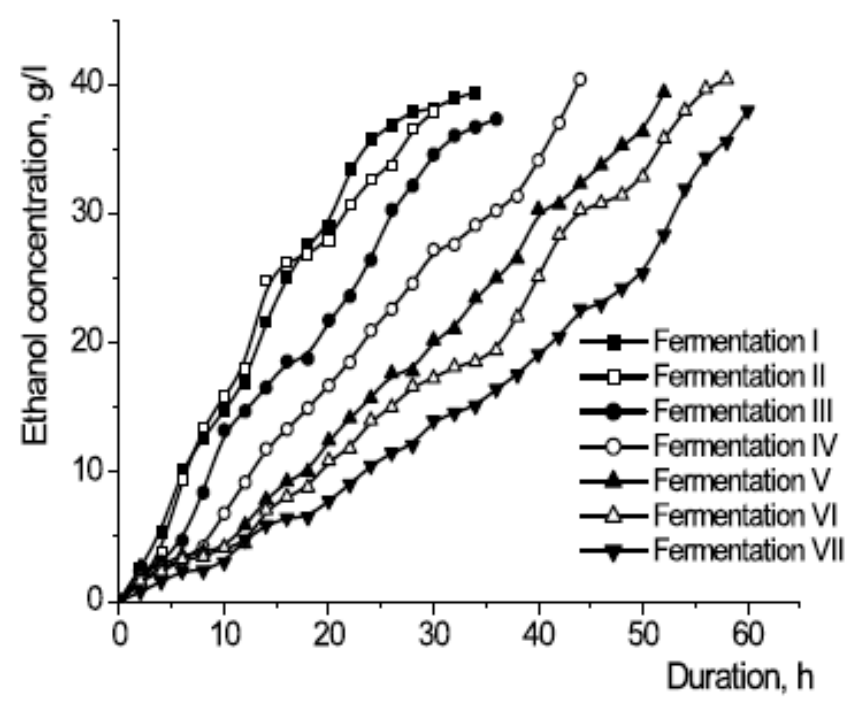

$$
\mathrm{C}_{\mathrm{S}}=150 \mathrm{~g} / 1
$$

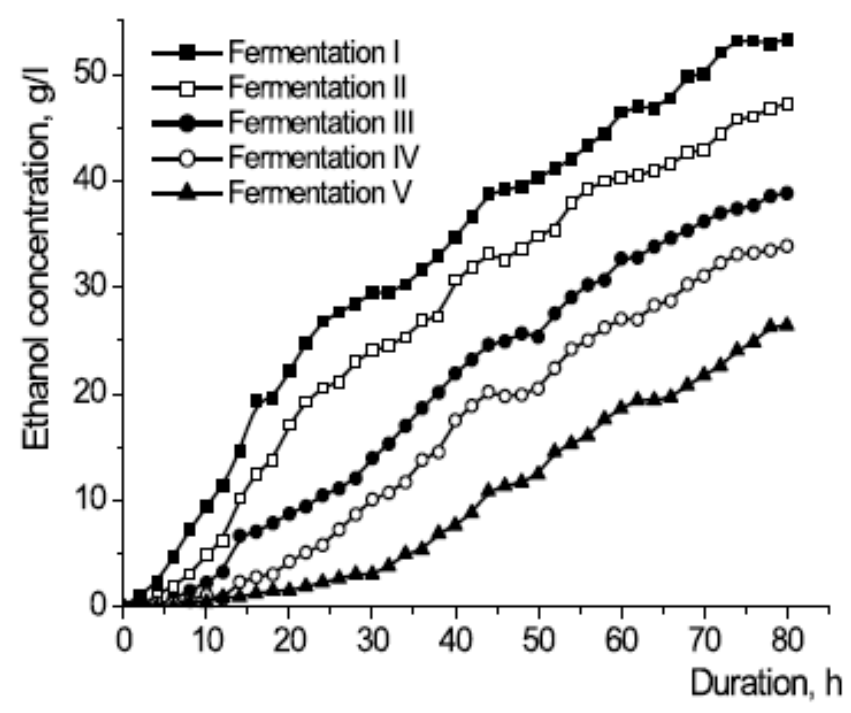

Fig. (5). Variation of ethanol concentration for biocatalyst particles diameter of $4 \mathrm{~mm}$ and $\phi=0.07$.

The analysis of the variation of substrate conversion yield offers more suggestive information regarding the effect of cells immobilization on the ethanol production efficiency. In this context, Fig. (7) indicates the dependence of this parameter on the size and concentration of biocatalyst particles related to the duration of the first fermentation cycle.

In all cases, the value of $\mathrm{Y}_{\mathrm{P} / \mathrm{S}}$ remains constant for a certain glucose concentration and biocatalyst characteristics, indifferent of the number of fermentation cycles. This result cumulated with the reduction of the fermentation rate by increasing the number of fermentation cycles suggest that the extension of the process duration does not lead to the formation of supplementary amounts of secondary compounds compared to the first cycle.
The influence of the biocatalyst particles size has to be correlated with their volumetric fraction. Thus, for the lowest volumetric fraction, $\phi=0.07$, for all considered sizes of the particles, the yield of substrate conversion decreases with the increase of glucose initial concentration from 50 to $150 \mathrm{~g} / 1$. Because the results have been related to the first fermentation duration, the variation of $\mathrm{Y}_{\mathrm{P} / \mathrm{S}}$ cannot be attributed to the increase of substrate concentration for the same amount of yeast cells. In these circumstances, the diminution of $\mathrm{Y}_{\mathrm{P} / \mathrm{S}}$ can be explained by the appearance and intensification of substrate inhibitory phenomenon. By increasing the particles size, and, therefore, by enhanced the importance of the internal diffusion resistance, the values of $\mathrm{Y}_{\mathrm{P} / \mathrm{S}}$ obtained for $150 \mathrm{~g} / \mathrm{l}$ glucose become closer to those for lower substrate concentrations, due to the attenuation of the 


$$
\mathrm{CS}_{\mathrm{S}}=50 \mathrm{~g} / 1
$$

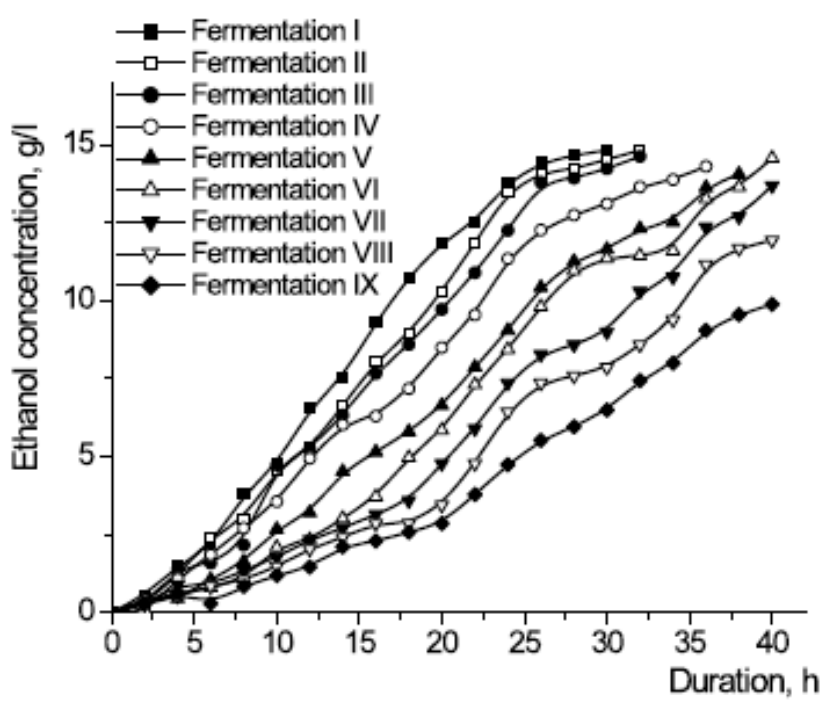

$$
\mathrm{C}_{\mathrm{S}}=150 \mathrm{~g} / 1
$$

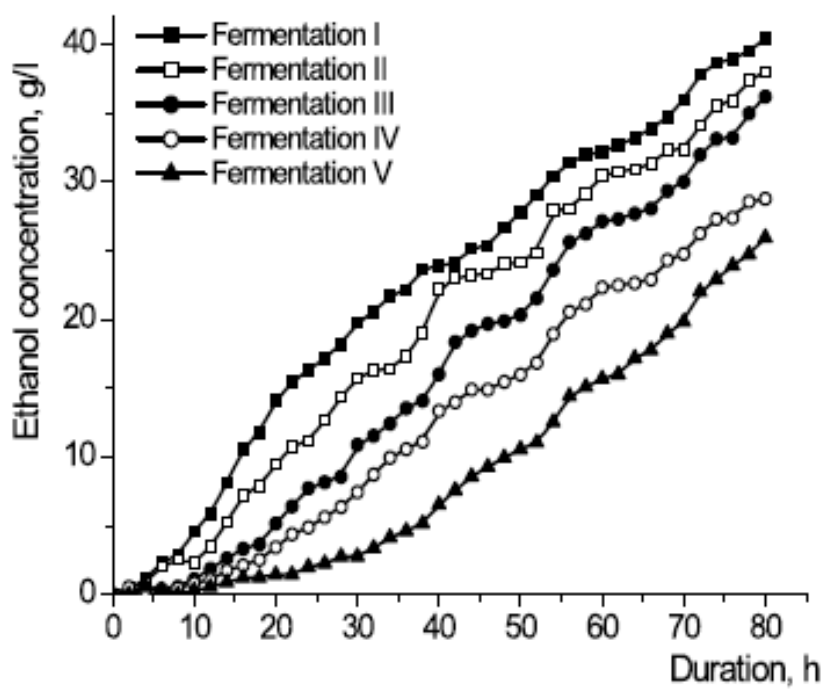

$$
\mathrm{C}_{\mathrm{S}}=100 \mathrm{~g} / 1
$$

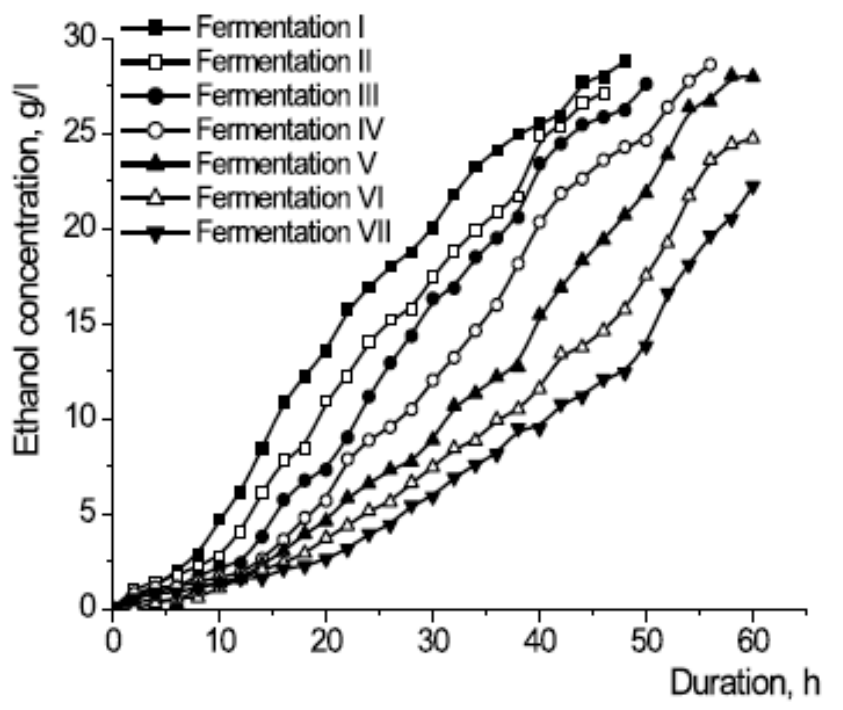

Fig. (6). Variation of ethanol concentration for biocatalyst particles diameter of $5.2 \mathrm{~mm}$ and $\phi=0.07$.

negative effect of substrate inhibition. This result supports the above conclusion.

The substrate conversion yield is reduced by enlarging the biocatalyst particles. This dependence is the consequence of the decrease of the substrate internal diffusion rate and of the increase of its concentration gradient between the surface and the inner regions of the particle. For $\phi=0.07, \mathrm{Y}_{\mathrm{P} / \mathrm{S}}$ varied from 0.26 , for a particle diameter of $5.2 \mathrm{~mm}$ and initial glucose concentration of $150 \mathrm{~g} / 1$, to 0.40 , for $4 \mathrm{~mm}$ diameter and $50 \mathrm{~g} / 1$ glucose.

Although most of the above variations are valid also for more concentrated suspensions of biocatalyst particles, the increase of the glucose concentration exhibits a contrary effect on the substrate conversion yield (Fig. 7). Due to the high amount of biocatalysts, the average glucose concentration inside the alginate particles is low, the increase of the substrate concentration having an important favorable influence on the fermentation performance.

\section{Kinetic Parameters}

The rate of the biochemical reactions in heterogeneous systems is lower than that recorded for homogeneous media, owing to the radial decreasing of the substrate concentration inside the biocatalyst particles. For the heterogeneous systems, not only the value of the biochemical reaction rate is affected, but also the kinetic model is modified compared to the ideal models describing the substrate consumption or product formation.

For these reasons, the kinetic parameters of the biochemical reactions which involve immobilized cells or 


$$
\mathrm{C}_{\mathrm{S}}=50 \mathrm{~g} / 1
$$
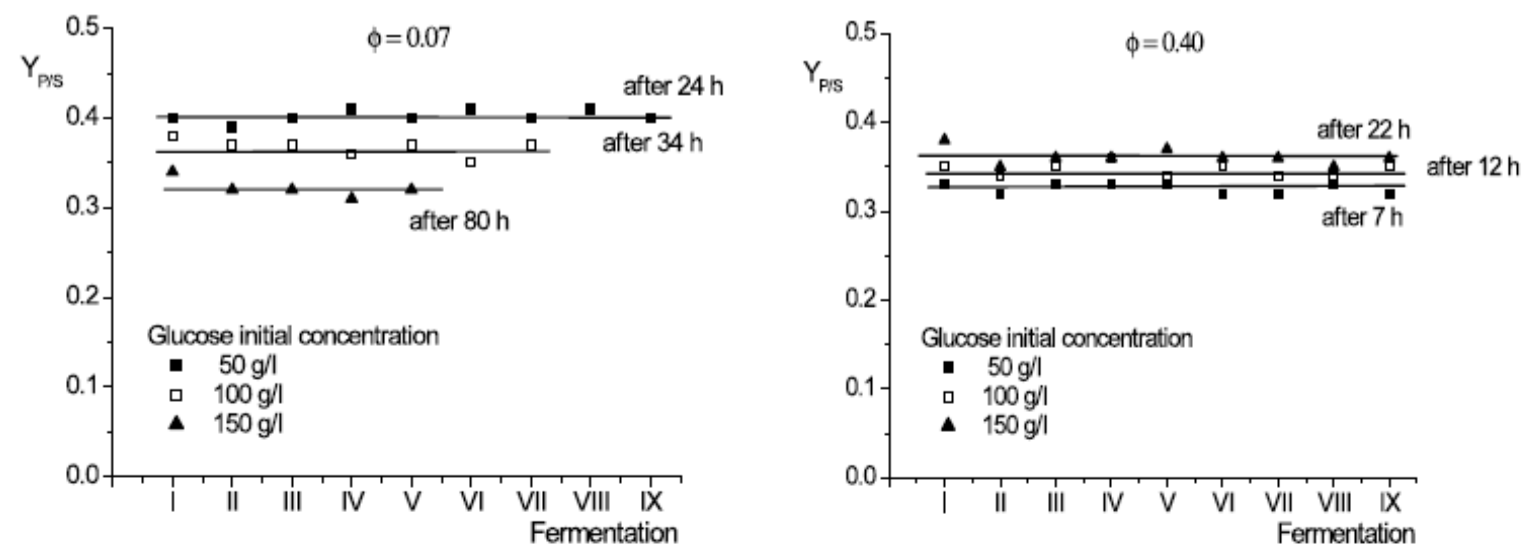

$$
\mathrm{C}_{\mathrm{S}}=100 \mathrm{~g} / 1
$$
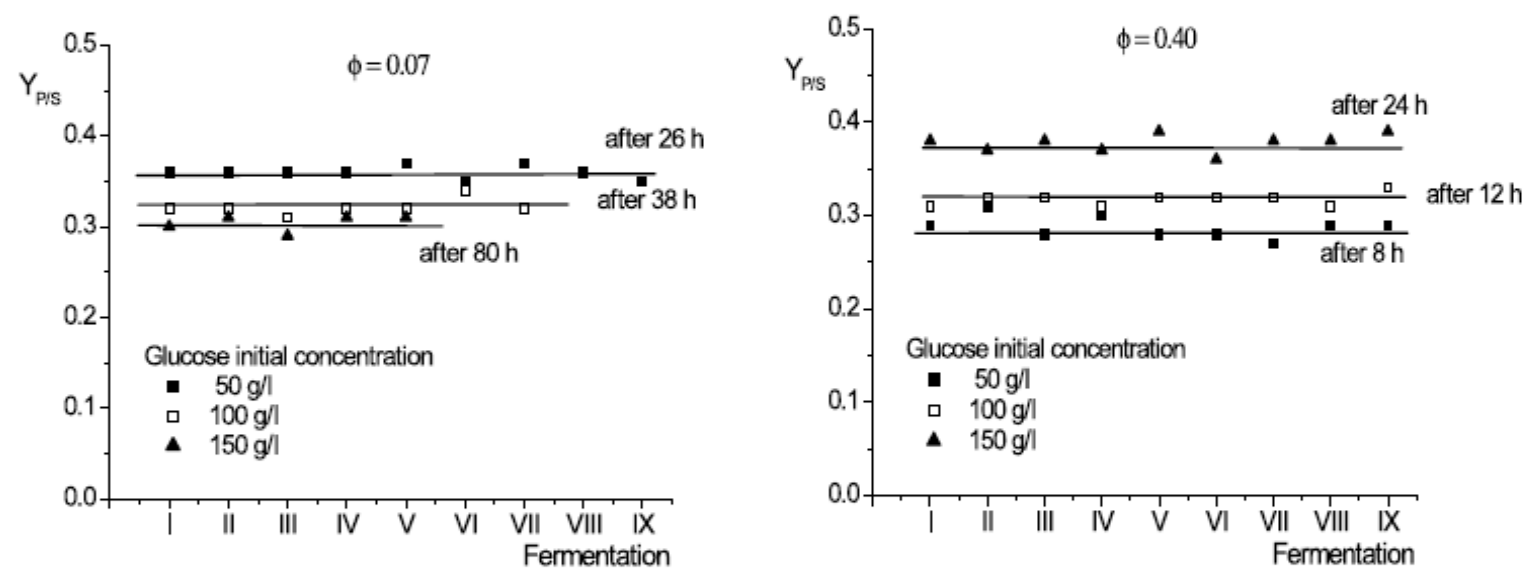

$$
\mathrm{C}_{\mathrm{S}}=150 \mathrm{~g} / 1
$$
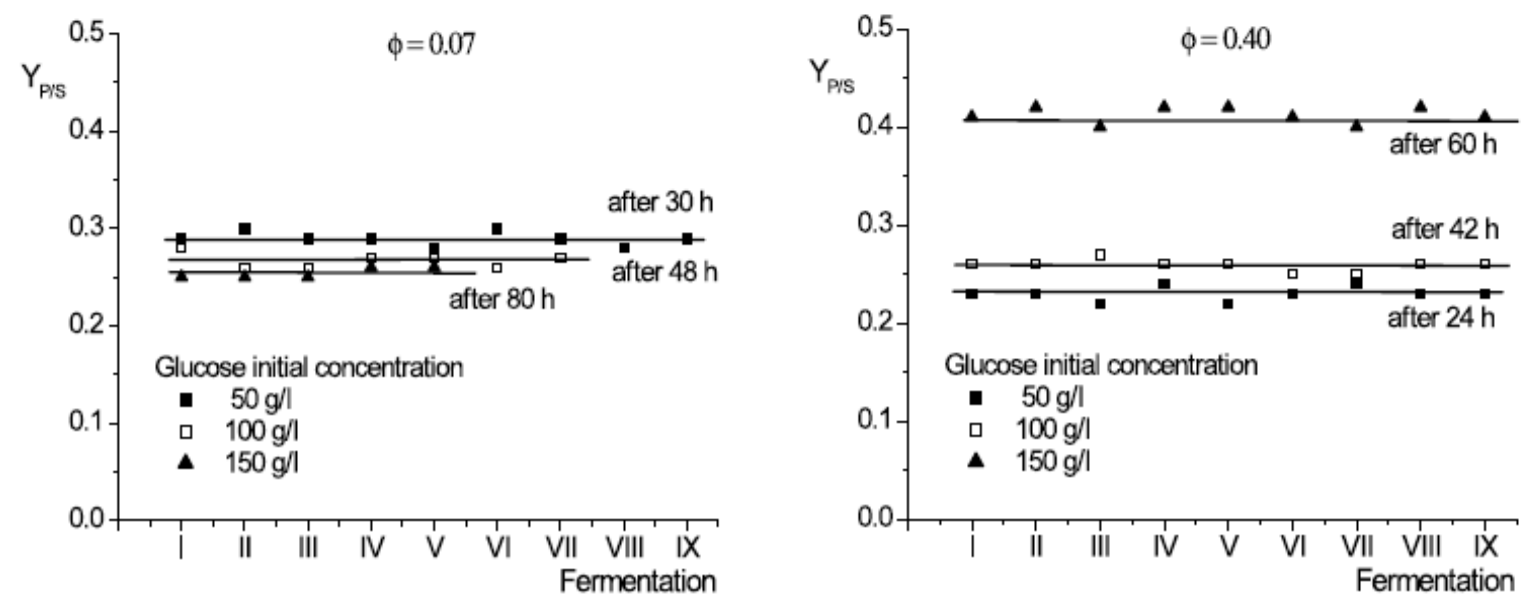

Fig. (7). Variation of glucose consumption yield.

enzymes differ from those corresponding to the homogeneous media. For the analyzed fermentation systems, the ethanol formation can be mathematically described by means of a modified Michaelis-Menten equation [20]:
$v_{P}=\frac{V \cdot C_{C} \cdot C_{S}}{K_{M}^{\prime}+C_{S}}$

The concentration of the yeast cells in medium is calculated with the expression: 


$$
\phi=0.07
$$

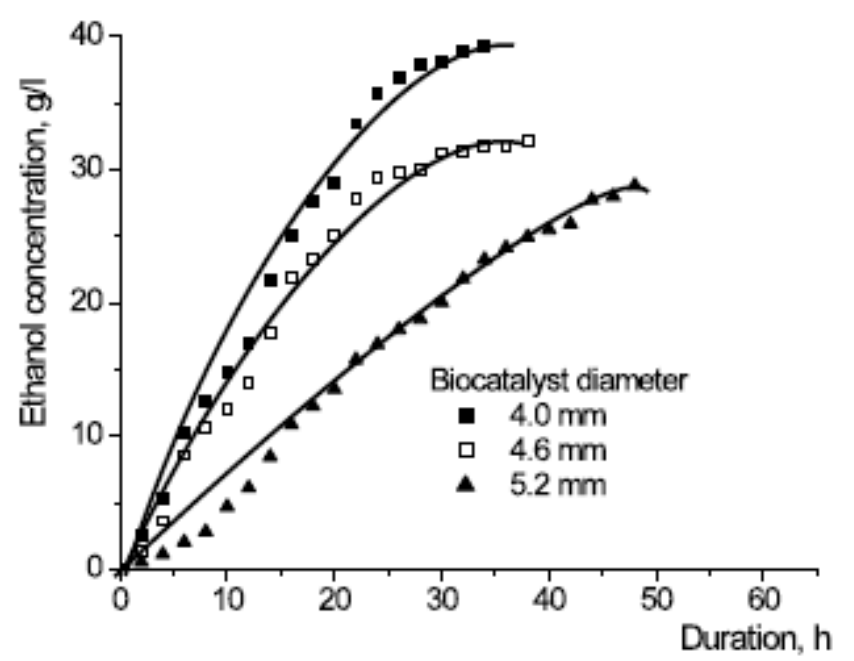

$$
\phi=0.40
$$

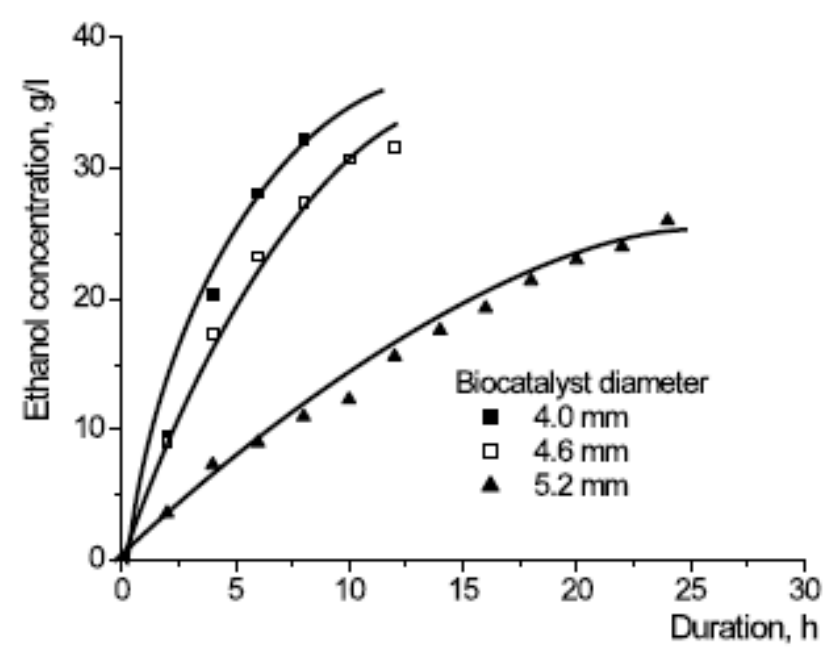

Fig. (8). Variation of ethanol concentration for the first fermentation cycle and $100 \mathrm{~g} / 1$ glucose.

$C_{C}=C_{C B} \cdot \phi$

The eq. (2) can be used for fermentation systems without inhibitory phenomena. But, as it was previously presented, although their magnitude was diminished by immobilization, the inhibitory effects occur also in the case of alcoholic fermentation with immobilized yeast cells, the most important being that induced by glucose. Therefore, taking into account the substrate inhibition, the Michaelis-Menten equation can be written for the immobilized cells as follows [23]:

$v_{P}=\frac{V \cdot C_{C} \cdot C_{S}}{K_{M}^{\prime}+C_{S}+\frac{C_{S}^{2}}{K_{I}}}$

The kinetic parameters, $\mathrm{V}, \mathrm{K}^{\prime}{ }_{\mathrm{M}}$ and $\mathrm{K}_{\mathrm{I}}$ can be estimated by Linewever-Burk linearization method adapted to the studied conditions and considering $\mathrm{K}_{\mathrm{M}}{ }_{\mathrm{M}}<<\mathrm{C}_{\mathrm{S}}$ :

$\frac{1}{v_{P}}=\frac{1}{V \cdot C_{C}}+\frac{C_{S}}{V \cdot C_{C} \cdot K_{I}}$

Thus, by plotting the dependence between $\frac{1}{v_{P}}$ and substrate concentration, the straight line having the slope equal with $\frac{1}{V \cdot C_{C} \cdot K_{I}}$ is obtained. Its intercept from the ordinate is $\frac{1}{V \cdot C_{C}}$. The apparent Michaelis-Menten constant can be calculated using its definition (it represents the value of the substrate concentration which corresponds to the half of the maximum rate of ethanol production).

For respecting the accuracy of the results and for avoiding the negative influence of the mechanical lysis of biocatalyst particles, the calculations have been made only for the first fermentation cycle. The ethanol production rate has been determined by means of the variations plotted in Fig. (8).

The obtained straight lines are plotted in Figs. $(\mathbf{9}, \mathbf{1 0})$ for two volumetric fractions of biocatalyst particles, 0.07 and 0.40 , respectively. The obtained values are given in Table $\mathbf{1}$.

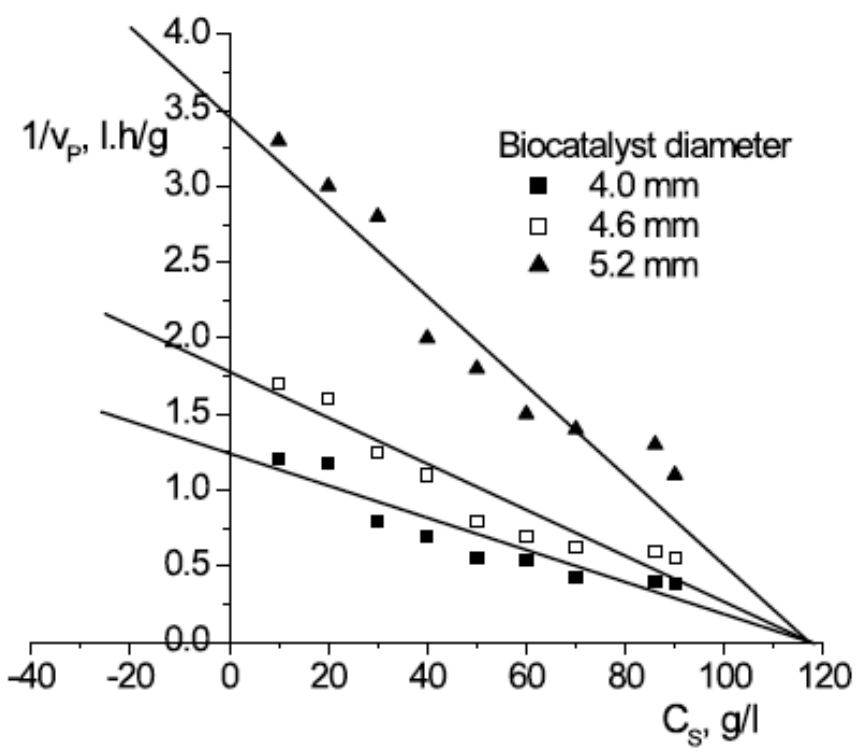

Fig. (9). Lineweaver-Burk plot for $\phi=0.07$.

These results indicate that the inhibition constant has an unique value indifferent of the biocatalyst particles size, but depending on their concentration. Thus, $\mathrm{K}_{\mathrm{I}}$ is decreased by increasing the particles volumetric fraction, result that suggests the attenuation of the inhibitory effect induced by glucose.

The apparent Michaelis-Menten constant is not influenced by the size and concentration of biocatalyst particles, its average calculated value being of $18.14 \mathrm{~g} / \mathrm{l}$.

The maximum rate of ethanol production is favorably influenced by the increase of the biocatalysts concentration, 
Table 1. The Values of Kinetic Parameters from Eq. (4)

\begin{tabular}{|c|c|c|c|c|c|}
\hline$\phi$ & Biocatalyst Diameter, mm & $\mathrm{C}_{\mathrm{C}}, \mathrm{g} / \mathbf{l}$ d.w. & $\mathrm{V}, \mathrm{g} / \mathrm{l} . \mathrm{h}$ & $K_{I}, g / l$ & $\mathrm{~K}_{\mathrm{M}}, \mathrm{g} / \mathbf{l}$ \\
\hline \multirow{2}{*}{0.07} & 4.0 & \multirow{2}{*}{0.35} & 2.286 & \multirow{2}{*}{117.82} & 18.03 \\
\hline & 5.2 & & 0.816 & & 18.18 \\
\hline \multirow{2}{*}{0.40} & 4.0 & \multirow{2}{*}{2.00} & 3.125 & \multirow{2}{*}{89.48} & 18.22 \\
\hline & 5.2 & & 1.136 & & 18.30 \\
\hline
\end{tabular}

but is affected by their size enlargement. In this case, the increase of the particles volumetric fraction from 0.07 to 0.40 led to the acceleration of the maximum rate for 1.30 1.35 times, due to the increase of the amount of active cells in medium and to the diminution of the inhibitory effect magnitude. On the other hand, the enlargement of the particles from the diameter of $4 \mathrm{~mm}$ to $5.2 \mathrm{~mm}$ determined the reduction of maximum rate for about 2.8 times, as the result of the enhancement of the resistance to the internal diffusion of glucose.

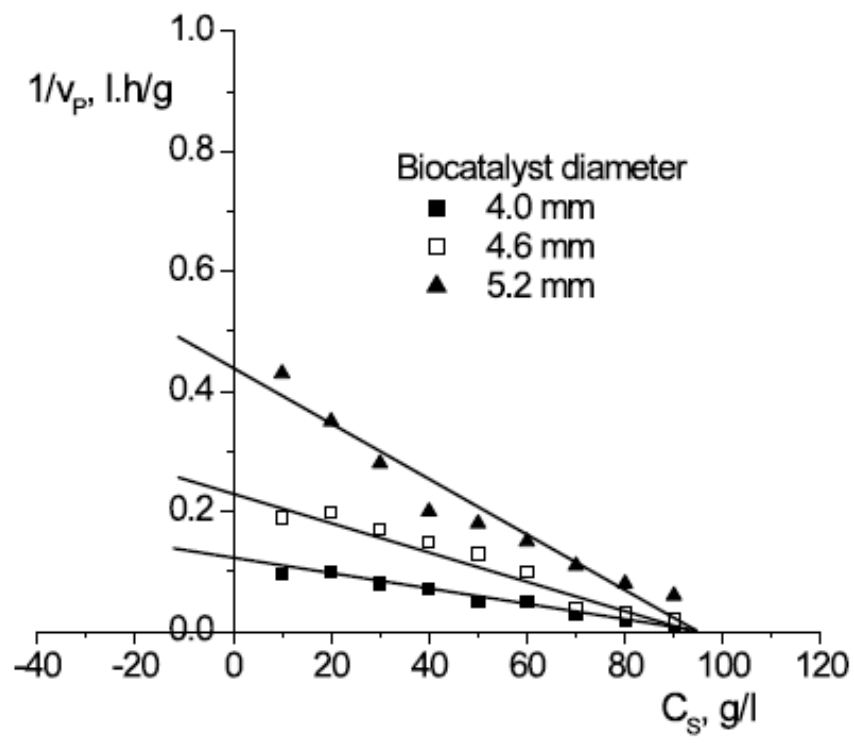

Fig. (10). Lineweaver-Burk plot for $\phi=0.40$.

By comparing these results to those reported by Aiba et $a l$. for alcoholic fermentation with free $S$. cerevisiae cells under ethanol inhibition conditions [19], the following conclusions can be drawn:

a. indifferent of the size of biocatalyst particles, the maximum rate of ethanol biosynthesis is superior to that reached for the homogeneous media containing $30 \mathrm{~g} / 1$ ethanol, due to the attenuation of the inhibitory effect by the internal diffusion $(\mathrm{V}=0.75 \mathrm{~g} / \mathrm{l}$ obtained by Aiba, et al. [19]);

b. the apparent Michaelis-Menten constant was significant greater than that obtained by Aiba et al. $\left(\mathrm{K}_{\mathrm{M}}^{\prime}=0.50 \mathrm{~g} / \mathrm{l}\right)$, also due to the internal diffusion.

Besides the positive effect exhibited by the attenuation of the inhibitory phenomena, the immobilization of
S. cerevisiae cells affects the fermentation rate compared to the systems without inhibition containing free yeast cells. Therefore, the kinetic studies on the alcoholic fermentation carried out by Hopkins and Roberts for media containing $100 \mathrm{~g} / 1$ glucose and $10 \mathrm{~g} / 1$ yeasts led to higher values of maximum rate, $21.3 \mathrm{~g} / \mathrm{l} . \mathrm{h}$, and Michaelis-Menten constant, $1.92 \mathrm{~g} / 1$ [24].

\section{CONCLUSIONS}

The studies on the substrate consumption and product formation rates during the alcoholic fermentation with immobilized $S$. cerevisiae cells and glucose substrate using a bioreactor with stirred beds of biocatalysts indicated the possibility to use these biocatalysts for five to over nine fermentation cycles, in function of the substrate concentration and biocatalyst characteristics. Moreover, due to the diffusion inside the biocatalyst particles, the inhibitory phenomena are avoided, the microbial activity being preserved.

Using a specific mathematical model for ethanol formation in the investigated systems, the kinetic parameters $\mathrm{V}, \mathrm{K}_{\mathrm{I}}$ and $\mathrm{K}_{\mathrm{M}}{ }_{\mathrm{M}}$ have been estimated and compared with their values previously reported for alcoholic fermentation in homogeneous media with or without inhibitory effects.

\section{ACKNOWLEDGEMENT}

This work was included in the Grant PNCDI II 21048/2007 supported by the National Centre for Programs Management (CNMP)

\section{ABBREVIATIONS}

$\mathrm{C}_{\mathrm{C}}=$ Yeast cells concentration in medium, g/l d.w.

$\mathrm{C}_{\mathrm{CB}}=$ Yeast cells concentration inside the biocatalyst particle, g/l d.w.

$\mathrm{C}_{\mathrm{P}}=$ Product concentration, $\mathrm{g} / 1$

$\mathrm{C}_{\mathrm{S}}=$ Substrate concentration, $\mathrm{g} / \mathrm{l}$

$\mathrm{C}_{\mathrm{SC}}=$ Consumed substrate concentration, $\mathrm{g} / \mathrm{l}$

$\mathrm{K}_{\mathrm{I}}=$ Inhibition constant, $\mathrm{g} / 1$

$\mathrm{K}_{\mathrm{M}}^{\prime}=$ Apparent Michaelis-Menten constant, $\mathrm{g} / \mathrm{l}$

$\mathrm{V}=$ Maximum rate of product formation, $\mathrm{g} / \mathrm{l} . \mathrm{h}$

$\mathrm{V}_{\mathrm{P}}=$ Rate of product formation, $\mathrm{g} / \mathrm{l} . \mathrm{h}$

$\phi=$ Volumetric fraction of biocatalist particles in medium 


\section{REFERENCES}

[1] Caşcaval D, Galaction AI. The European colour of biotechnology is white. Rom Biotechnol Lett 2007; 12: 3489-94.

[2] Takamitsu I, Izumida H, Acagi Y, Sakamoto M. Continuous ethanol fermentation in molasses medium using Zymomonas mobilis immobilized in photo-cross linkable resin gels. J Ferment Bioeng 1993; 75: 32-5.

[3] Flinckinger MC, Drew SW. Energy metabolism, microbial and cells. Encycl Bioprocess Technol: Ferment Biocatal Biosep 1999; 2: 39 .

[4] Najafpour G, Younsei H, Syahidah K, Ismail K. Ethanol fermentation in an immobilizez cell reactor using $S$. cerevisiae. Biores Technol 2004; 92: 251-60.

[5] Staniszewski M, Kujawski W, Lewandowska M. Semi-continuous ethanol production in bioreactor from whey with co-immobilized enzyme and yeast cells followed by pervaporative recovery of product - kinetic model predictions considering glucose repression. J Food Eng 2009: 91: 240-9.

[6] Yamada T, Fatigati MA, Zhang M. Performance of immobilized Zymomonas mobilis 31821 (pZB5) on actual hydrolysates produced Arkeol technology. Appl Biochem Biotechnol 2002; 98: 899-907.

[7] Nigam JN. Continuous ethanol production from pineapple cannery waste using immobilized yeast cells. J Biotechnol 2000; 80: 18993.

[8] Williams D, Munnecke DM. The production of ethanol by immobilized yeast cells. Biotechnol Bioeng 1981; 23: 1813-25.

[9] Rivaldi JD, Sarrouh BF, da Silva SS. An evaluation of different bioreactor configurations with immobilized yeast for bioethanol production. Int J Chem Reactor Eng 2008; 6: A115.

[10] Pacheco AI, Gondim DR, Gonçalves LRB. Ethanol production by fermentation using iImmobilized cells of Saccharomyces cerevisiae in cashew apple bagasse. Appl Biochem Biotechnol 2009; 104: 1-9.

[11] Nikolic S, Mojovic L, Rakin M, Pejin D. Bioethanol production from corn meal by simultaneous enzymatic saccharification and fermentation with immobilized cells of Saccharomyces cerevisiae var. ellipsoideus. Fuel 2009; 88: 1602-7.

[12] Singh NL, Srivastava P, Mishra PK. Studies on ethanol production using immobilized cells of Kluyveromyces thermotolerans in a packed bed reactor. J Sci Ind Res 2009; 68: 617-23.
[13] Behera S, Kar S, Mohanty RC, Ray RC. Comparative study of bioethanol production from mahula (Madhuca latifolia L.) flowers by Saccharomyces cerevisiae cells immobilized in agar agar and Caalginate matrices. Appl Energy 2010; 87: 96-100.

[14] Lupăşteanu AM, Galaction AI, Caşcaval D. Comparative evaluation of radial impellers efficiency for bioreactors with stirred beds of immobilized cells. 1. Disperser sawtooth and Smith turbine. Rom Biotechnol Lett 2008; 13: 3821-36.

[15] Galaction AI, Lupăşteanu AM, Caşcaval D. Comparative evaluation of radial impellers efficiency for bioreactors with stirred beds of immobilized cells. 2. Pumper mixer and curved bladed turbine. Rom Biotechnol Lett 2009; 14: 4282-93.

[16] Galaction AI, Lupăşteanu AM, Caşcaval D. Comparative evaluation of radial impellers efficiency for bioreactors with stirred beds of immobilized cells. 3. Paddle with six blades and pitched bladed turbine. Rom Biotechnol Lett 2009; 14(5): 4681-93.

[17] Caşcaval D, Galaction AI, Lupăş̧eanu AM. Comparative evaluation of radial impellers efficiency for bioreactors with stirred beds of immobilized cells. 4. Studies on mechanical effect on biocatalysts integrity. Rom Biotechnol Lett 2010; 15: 4931-39.

[18] Caşcaval D, Galaction AI, Turnea M. Comparative analysis of mixing distribution in aerobic stirred bioreactor for simulated, yeasts and fungus broths. J Ind Microbiol Biotechnol 2007; 34: 3547.

[19] Aiba S, Shoda M, Nagatani M. Kinetic of product inhibition in alcohol fermentation. Biotechnol Bioeng 2000; 67: 671-90.

[20] Bailey JF, Ollis DF. Biochemical Engineering Fundamentals. New York: McGraw-Hill 1986.

[21] Ingram LO, Gomez PF, Lai X, Moniruzzaman M, Wood BE. Metabolic engineering of bacteria for ethanol production. Biotechnol Bioeng 1998; 58: 204-14.

[22] Nagodawithana TW, Steinkraus KH. Influence of the rate of ethanol production and accumulation on the viability of Saccharomyces cerevisiae in rapid fermentation. J Appl Environ Microbiol 1976; 31: 158-62.

[23] Doble M, Kruthiventi AK, Gaikar VG. Biotransformations and bioprocesses. New York: M. Dekker, Inc 2004.

[24] Hopkins RH, Roberts RH. The kinetics of alcoholic fermentation of sugars by brewer's yeast II. The relative rates of fermentation of glucose and fructose. Biochem J 1935; 29: 931-6.

(C) Galaction et al.; Licensee Bentham Open.

This is an open access article licensed under the terms of the Creative Commons Attribution Non-Commercial License (http: //creativecommons.org/licenses/by$\mathrm{nc} / 3.0 /$ ) which permits unrestricted, non-commercial use, distribution and reproduction in any medium, provided the work is properly cited. 